\title{
Effect of Bongi Me'e Liquid Soap Toward Staphylococcus Epidermidis
}

\author{
Farid Wajdi ${ }^{1 *}$, Suhratul Aini ${ }^{2}$, Fitria Aprillah Nardi ${ }^{3}$, Desy Komalasari ${ }^{3}$ \\ ${ }^{1}$ Department of Chemistry, Faculty of Mathematics and Natural Science, University of Mataram. \\ Indonesia. \\ ${ }^{2}$ Chemistry Education Division, University of Mataram. Indonesia. \\ ${ }^{3}$ Department of Physics, Faculty of Mathematics and Natural Science, University of Mataram. Indonesia. \\ *Email: faridwajdi784@gmail.com
}

Received July 26, 2018; Accepted February 12, 2019

\begin{abstract}
Acne or commonly referred as acne vulgaris is a chronic skin disease due to abnormalities of sebum production in sebaceous glands caused by staphylococcus epidermis bacteria. Acne treatment is usually done by using antibiotics, both topical and oral like Clindamycin $1 \%$. However, the long-term use of antibiotics might lead to resistant of propionibacterium acne strains or immune to clindamycin $1 \%$. People in Bima, Indonesia particulary in Wawo district have local wisdom, that is facial using Bongi Me'e which is a traditional scrubs made of rice, tamarind, and temu giring extract that officacious as antibacterial. The purpose of this study was to determine the effectiveness of Bongi Me'e liquid soap as the antibacterial against Staphylococcus epidermis. In this research, four soap formulas were formulated and tested using well diffusion method. The inhibitory zone test indicated that the highest diameter of inhibition zone obtained in the formula 1 of $29.3 \mathrm{~mm}$, followed by the formula 2 of $28 \mathrm{~mm}$, formula 4 of $26.6 \mathrm{~mm}$, and formula 3 that has smallest inhibitory zone by $25 \mathrm{~mm}$. So, the antibacterial Bongi Me'e liquid soap was effective to inhibit acne-cause bacteria Staphylococcus epidermis.
\end{abstract}

Keywords: Bongi Me'e, liquid soap, Staphylococcus epidermis, the effectiveness of agar diffusion

\section{INTRODUCTION}

Acne or commonly referred as Acne vulgaris is a chronic skin disease due to abnormalities of sebum production in sebaceous glands that can be caused by Staphylococcus epidermis bacteria [1-3]. Acne vulgaris gives bad effect for the teenagers both physicly and physologicly. Those with acne tend to feel depression, anxiety, and hide away from social interaction [4-5].

Acne treatment can be done using antibiotic e.g. Clindamycin $1 \%$. However, the use of it for long time results in the existence of Propionibacterium Acnes that is resistent to Clindamycin [6-7]. People in Bima particularly in Wawo district have local wisdom of using Bongi Me'e as their facial treatment to keep their skin health. Bongi Me'e is a traditional scrub formulation made of white rice (Oryza sativa $L$ ), tamarind (Thamarindu indica), temu giring (Curcuma heyneana val) extract. Even though it has been used long as skin care, the scientific evidence of it as well as the formulation does not find yet. The objective of this research was to figure out the effectivity of antibacterial Bongi Me'e liquid soap against Staphylococcus epidermis as the acne-causing bacteria. The further research was also done due to the urgency of finding natural ingredients as an alternative to replace chemical ingredients in antibacterial soap because of its disadvantage hazardous effect.

In Bahasa, Bongi Me'e means Black rice. The ingredients consists of banggulae or temu giring (Curcuma heyneana val.), bongi or white rice (Oryza sativa L), mange or tamarind (Thamarindu indica). The blend of these ingredients has some effect; smooth the skin, brighten the skin, prevent acne, reduce body odor, tighten the skin, shrink the pores and as an anti-oxidant. This is due to the content of white rice (Oryza sativa L); carbohydrate, protein, fat, color pigment, mineral, vitamin as well as B6, B12 and B1.

Based on phytochemicals identification, tamarind contains flavonoid, tannin, saponin, and glikosida. These substances are effective as antibacterial. While temu giring contains some antibacterial; flavonoid, tanin, saponin, essential oil, etc. that able to disrupt and kill the grow of bacteria [8-11].

\section{METHOD}

1. Materials and equipment

The equipment used in this research are laminar air flow, autoclave, Erlenmeyer (1 L), analytical scale, funnel, filter paper, $\mathrm{pH}$ stick, blender, micropipette, ruler, beaker glass (500 $\mathrm{ml}$ and $250 \mathrm{ml}$ ), measuring glass (10 and 25 
$\mathrm{ml}$ ), petri dish, swab, incubator, ose, pipette, secer, stirrer, refrigerator, hotplate, pincet, sterile knife, rotary evorator and magnetic stirrer.

The materials used in this research are The materials used in this research are 1 plate of Staphylococcus epidermis bacterium, Curcuma heyneana, tamarind, white rice, aquades, $\mathrm{NaOH} 4 \mathrm{M}$, coconut oil, NA media, NB / $\mathrm{NaCl}$ media, and Amoxilin standard, 96\%, 1 roll of aluminum foil, label paper, sterile cotton, sunlight soap, 1 roll of cling wrapping, spiritus and two roll of tissue.

2. Sample preparation

The samples used in this study were temu giring (Curcuma heyneana val.), White rice (Oryza sativa L), and tamarind (Thamarindu indica). White rice were roasted first to remove the moisture content, and then blended. The part of the temu giring used was the rhizome that was first cleaned, peeled, dried and then blended. Section of tamarind used is part of the fruit flesh that has been separated with the seeds then dried in the air.

3. Sample extraction

The samples extraction process was done using maceration for 48 hours. Each sample was weighed $300 \mathrm{gr}$ and soaked in 600 $\mathrm{ml}$ ethanol $96 \%$ using Erlenmeyer $1 \mathrm{~L}$. Then samples were filtered to get the extract and pasted using Rotary evorator.

4. Liquid soap making process

The extracted sample, $\mathrm{NaOH} 4 \mathrm{M}$ and coconut oil were weighed based on the formulation (Table 1). The coconut oil was heated at $60{ }^{\circ} \mathrm{C}$ and then cooled and followed by the adding of $\mathrm{NaOH} 4 \mathrm{M}$ with constant stirring. After the base soap coagulate, $150 \mathrm{ml}$ aquades was added gradually and followed by the adding of samples extracted. It was stirred constantly until the liquid soap formed.

5. Soap quality control

The quality control was done using organoleptic test using 20 panelists based on the color, foam, freshness and odor. The scale used consist of four ranges: very like, like, less like and dislike. The test result presented in the form of table so can be seen as comparation of combination.

6. Antibacterial activity test of Liquid Soap

The antibacterial activity test was done using agar diffusion. The media consisted of Nutrient Agar, and $\mathrm{NaCl}$ liquid. The bacteria isolates was obtained from microbiology laboratory, Faculty of Natural Science University of Mataram. The bacteria isolates was first rejuvenated to get the bacteria stock, and to make it easier in repeating the test. The isolates were prepared and transferred to $\mathrm{NaCl}$ liquid medium taken with swab and dispersed to agar medium. Hole was made on the media, then $50 \mu \mathrm{g}$ of the liquid soap was added into it. After that the incubation was set for 24 hour at $37{ }^{\circ} \mathrm{C}$ then the inhibition zone can be observed.

Table 1 Liquid soap formulation

\begin{tabular}{lcccc}
\hline Ingredients & F1 & F2 & F3 & F 4 \\
\hline White rice & $4 \mathrm{ml}$ & $2 \mathrm{ml}$ & $2 \mathrm{ml}$ & $4 \mathrm{ml}$ \\
$\begin{array}{l}\text { Curcuma } \\
\text { heyneana }\end{array}$ & $3 \mathrm{ml}$ & $3 \mathrm{ml}$ & $4 \mathrm{ml}$ & $2 \mathrm{ml}$ \\
Tamarind & $2 \mathrm{ml}$ & $4 \mathrm{ml}$ & $3 \mathrm{ml}$ & $3 \mathrm{ml}$ \\
NaOH & $1 \mathrm{~L}$ & $1 \mathrm{~L}$ & $1 \mathrm{~L}$ & $1 \mathrm{~L}$ \\
Aquades & $1 \mathrm{~L}$ & $1 \mathrm{~L}$ & $1 \mathrm{~L}$ & $1 \mathrm{~L}$ \\
Coconut oil & $1 \mathrm{~L}$ & $1 \mathrm{~L}$ & $1 \mathrm{~L}$ & $1 \mathrm{~L}$ \\
Perfume & $1 \mathrm{ml}$ & $1 \mathrm{ml}$ & $1 \mathrm{ml}$ & $1 \mathrm{ml}$ \\
\hline
\end{tabular}

\section{RESULT AND DISCUSSION}

The maceration method was chosen due to the easiness to get its equipment as well as its ability to attract particular compound of the samples, either heat-resistant or non-heating resistant compound.

The inhibition test of Bongi Me'e liquid soap on Staphylococcus epidermis bacteria was done using hole diffusion methode; deternine the inhibition zone around the hole that contain Bongi Me'e liquid soap. the wider zone of inhibition formed indicated the more effective the compound of the substance as antibacterial. Tests were performed on 4 soap formulas with positive control of amoxilin and negative control of ethanol $96 \%$. In this research the repetition was done three times, so that the data obtained as many as 12 data diameter of inhibition zone. The results of Bongi Me'e liquid soap inhibition test can be seen in Table 2.

The results of Bongi Me'e liquid soap inhibition test against staphylococcus epidermidis bacteria showed that all formulas (Formula 1, formula 2, formula 3 and formula 4) had inhibitory power. Table 2 showed that the highest mean inhibitory zone diameter was obtained in formula 1 with a diameter of 29.3 $\mathrm{mm}$, then formula 2 of $28 \mathrm{~mm}$, formula 4 of 26.6 $\mathrm{mm}$ and formula 3 having the smallest inhibit zone of $25 \mathrm{~mm}$. Inhibiton zone of formula 1, 2, 3 and 4 is compared with the inhibitory zone contained in the positive control of amoxilin 50 $\mu \mathrm{g}$ of $60 \mathrm{~mm}$, then the inhibitory power of all the formulas against Saphylococcus epidermidis is smaller. However, Bongi Me'e liquid soap has potential as an antibacterial because it can inhibit the growth of Staphylococcus epidermidis which is indicated by the inhibition zone around the disk (medium). 
Table 2. Inhibition zone of Bongi Me'e liquid soap

\begin{tabular}{ccccc}
\hline \multirow{2}{*}{ Treatment } & \multicolumn{3}{c}{ Repetition } & \multirow{2}{*}{ average } \\
\cline { 2 - 4 } & $\mathrm{U}_{1}$ & $\mathrm{U}_{2}$ & $\mathrm{U}_{3}$ & \\
\hline $\mathrm{F} 1$ & $30 \mathrm{~mm}$ & $28 \mathrm{~mm}$ & $30 \mathrm{~mm}$ & $29,3 \mathrm{~mm}$ \\
$\mathrm{~F} 2$ & $28 \mathrm{~mm}$ & $28 \mathrm{~mm}$ & $28 \mathrm{~mm}$ & $28 \mathrm{~mm}$ \\
$\mathrm{~F} 3$ & $25 \mathrm{~mm}$ & $25 \mathrm{~mm}$ & $25 \mathrm{~mm}$ & $25 \mathrm{~mm}$ \\
F4 & $26 \mathrm{~mm}$ & $27 \mathrm{~mm}$ & $27 \mathrm{~mm}$ & $26,6 \mathrm{~mm}$ \\
Positive Control & $60 \mathrm{~mm}$ & $60 \mathrm{~mm}$ & $60 \mathrm{~mm}$ & $60 \mathrm{~mm}$ \\
Negative Control & $0 \mathrm{~mm}$ & $0 \mathrm{~mm}$ & $0 \mathrm{~mm}$ & $0 \mathrm{~mm}$ \\
\hline
\end{tabular}

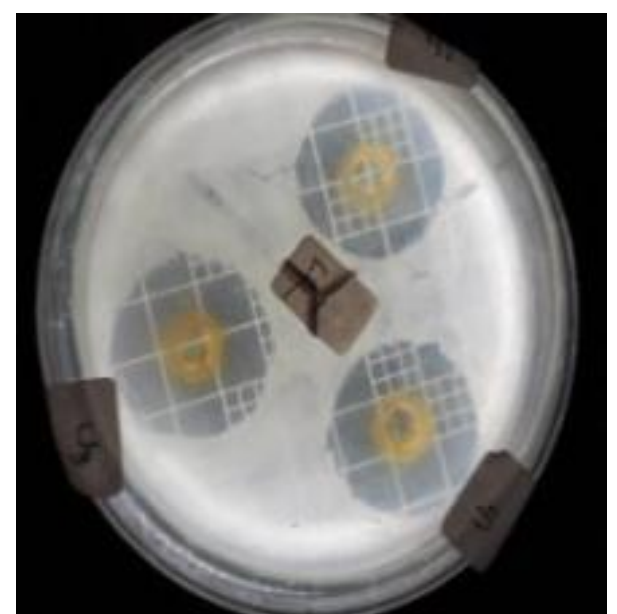

Formula 1

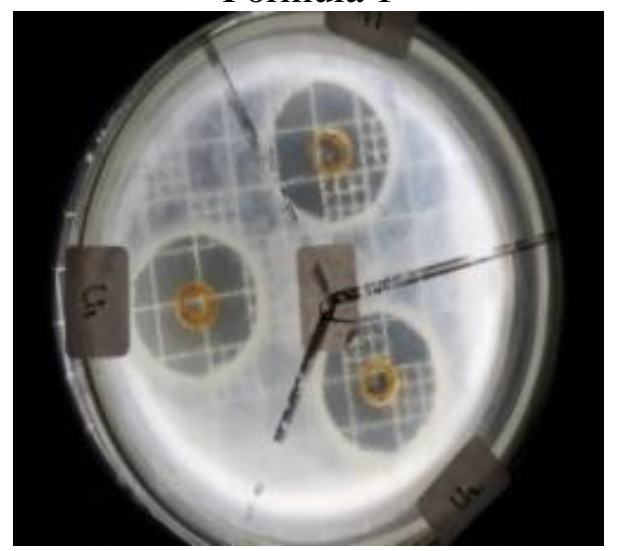

Formula 3

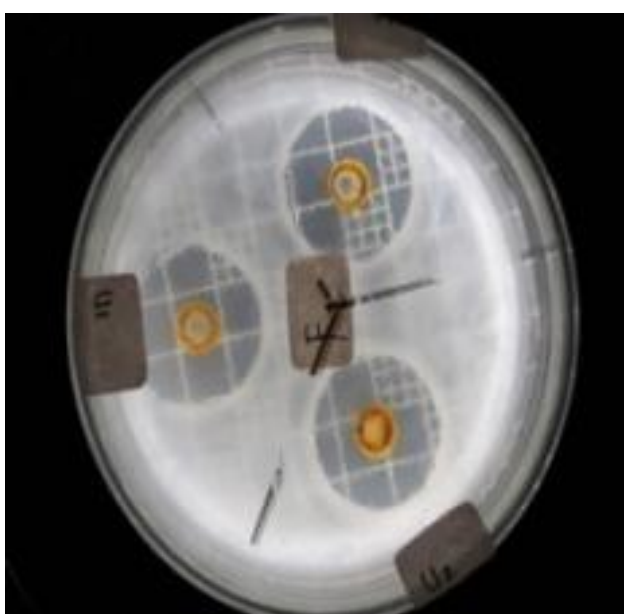

Formula 2

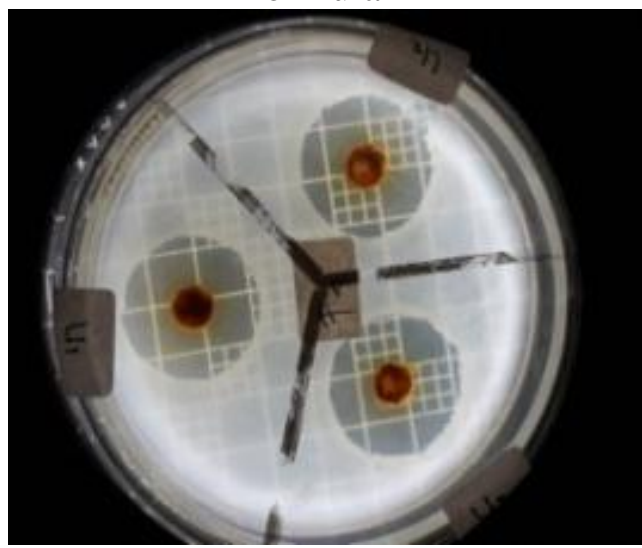

Formula 4

Figure 1. Inhibition zone of Bongi Me'e liquid soap

Description:

Formula 1: Inhibition zone of Bongi Me'e liquid soap (yellow color solution) shown by a clear zone.

Formula 2: Inhibition zone of Bongi Me'e liquid soap (yellow red color solution) shown by a clear zone.

Formula 3: Inhibition zone of Bongi Me'e liquid soap (yellow color solution) shown by a clear zone.

Formula 4: Inhibition zone of Bongi Me'e liquid soap (red brick color solution) shown by a clear zone.
Inhibition of bacterial growth is influenced by several factors; the first is the content of antibacterial compounds. Temu Giring and tamarind extract contain antibacterial compounds including tannins, flavonoids and saponins [12-15]. Tannin has antibacterial power, through the reaction with the cell membrane, tannin attacks the cell wall polypeptide so that the formation of the cell wall becomes less perfect and cause bacterial cell lysis due to osmotic pressure so that bacterial cells death [16-17]. Flavonoid is a disinfectant 
that works in a way of proteins denaturation, cause the metabolism activity of bacterial cell stop, while saponins can increase the permeability of bacterial cell membranes that change the membrane structure and function, causing denaturation of protein membrane so that cell membranes will be damaged and lysis resulting in bacterial cell death. The second factor is the presence of $\mathrm{NaOH}$ effect on the liquid soapy resistance of Bongi Me'e because of its antiseptic and antimicrobial properties, it has proved that $\mathrm{NaOH}$ is very effective for clearance of contamination of Gram positive and negative bacteria [18-19] (Sameng, 2013).

\section{CONCLUSION}

Based on the results of this study, it can be concluded that all soap formulas have inhibitory ability to the growth of Staphylococcus epidermidis bacteria. The results of the inhibitory test of all four formulas showed that the highest mean inhibitory zone diameter was obtained in formula 1 of $29.3 \mathrm{~mm}$, followed by formula 2 of $28 \mathrm{~mm}$, formula 4 of $26.6 \mathrm{~mm}$ and formula 3 having the smallest inhibit zone of 25 $\mathrm{mm}$. Thus, the four Bongi Me'e liquid soap formulas are quite effective in inhibiting Staphylococcus epidermis bacteria.

\section{References}

[1] Shivanand, P., Nilam, M., \& Viral, D. (2010). Herbs play an important role in the field of cosmetics. International Journal of PharmTech Research, 2(1), 632-639.

[2] Kumar, K. P., Bhowmik, D., Tripathi, K. K., \& Chandira, M. (2010). Traditional Indian Herbal Plants Tulsi and Its Medicinal Importance. Research Journal of Pharmacognosy and Phytochemistry, 2(2), 93-101.

[3] Yahya, H. (2009). Acne vulgaris in Nigerian adolescents-prevalence, severity, beliefs, perceptions, and practices. International journal of dermatology, 48(5), 498-505.

[4] Roeder, E., \& Wiedenfeld, H. (2013). Plants containing pyrrolizidine alkaloids used in the Traditional Indian Medicineincluding Ayurveda. Die Pharmazie-An International Journal of Pharmaceutical Sciences, 68(2), 83-92.
[5] Packianathan, N., \& Kandasamy, R. (2011). Skin Care with Herbal Exfoliants. Functional Plant Science and Biotechnology, 5(1), 94-97.

[6] Wathoni, N. A. S. R. U. L., Haerani, A., Yuniarsih, N., \& Haryanti, R. E. T. N. O. (2018). A review on herbal cosmetics in Indonesia. International Journal of Applied Pharmaceutics, 10(5), 13-16.

[7] Berson, D. S., Draelos, Z. K., \& Webster, G. F. (1995). Saving face: a treatment update for acne. Patient Care, 29(19), 20-36

[8] Evelina, L. W., \& Safitri, Y. (2019, August). Customer Experience Bali Natural Beauty Care Through Social Media. In 2019 International Conference on Information Management and Technology (ICIMTech) (Vol. 1, pp. 8286). IEEE.

[9] Narayanaswamy, R., \& Ismail, I. S. (2015). Cosmetic potential of Southeast Asian herbs: overview. Phytochemistry Reviews, 14(3), 419-428.

[10] Narayanaswamy, R., \& Ismail, I. S. (2015). Cosmetic potential of Southeast Asian herbs: an overview. Phytochemistry

Reviews, 14(3), 419-428.

[11] Saptarini, N. M., \& Herawati, I. E. (2017). Development And Evaluation Of AntiAcne Gel Containing Garlic (Allium Sativum) Against Propionibacterium Acnes. Development, 10(8).

[12] Batoro, J., \& Siswanto, D. (2017). Ethnomedicinal survey of plants used by local society in Poncokusumo district, Malang, East Java Province, Indonesia. Asian Journal of Medical and Biological Research, 3(2), 158-167.

[13] Nam, C. J., Han, Y. G., Kim, S. J., Kim, J. H., Oh, J. Y., Park, J. W., \& Lee, H. (1999). Studies Of Acne Treatment Using Oriental Herbs (New Approach To Select Anti-Acne agents). Journal of the Society of Cosmetic Scientists of Korea, 25(4), 111-121. 
[14] Bhatia, M., Siddiqui, N., \& Gupta, S. (2013). Abrus precatorius (L.): An evaluation of traditional herb. $J$ Pharm Res, 3, 3296-315.

[15] Bhowmik, D., Kumar, K. S., Yadav, A., Srivastava, S., Paswan, S., \& Dutta, A. S. (2012). Recent trends in Indian traditional herbs Syzygium aromaticum and its health benefits. Journal of Pharmacognosy and Phytochemistry, 1(1), 13-23.

[16] Xiang, S. B., Zhang, H., Zeng, H. X., Cao, H. A., Hen, Q. L., \& Wu, C. P. (2009). The Prevalence and Risk Factors of Middle School Students Acne in tropical and Subtropical Areas. The Chinese Journal of Dermatovenereology, (2), 28.

[17] Febriyani, E., Falah, S., Andrianto, D., \& Lastini, T. (2018). Identification of active compounds and anti-acne activity from extracts and fractions of surian (Toona sinensis) leaves planted in Sumedang, West Java, Indonesia. Biodiversitas Journal of Biological Diversity, 19(4), 1406-1412.

[18] Djati, M. S., \& Christina, Y. I. (2019). Traditional Indonesian rempah-rempah as a modern functional food and herbal medicine. Functional Foods in Health \& Disease, 9(4).

[19] Cornelia, M., \& Lessy, S. T. (2018). The Utilization of Edamame (Glycine max (L.) Merr) And Red Bean (Phaseolus vulgaris) As A Functional Beverage. Acta Chimica Asiana, 1(1), 11-16.

[20] Miglani, A., \& Manchando, R. K. (2015). Homeopathy: Observational study of Arctium lappa in the treatment of acne vulgaris. Journal of the Australian Traditional-Medicine Society, 21(3), 196-

197. 